\title{
Re-examining the relationship between the subject agreement morpheme and (in)definiteness in Northern Sotho
}

Author:

Mampaka L. Mojapelo

Affiliation:

${ }^{1}$ Department of African Languages, University of

South Africa, Pretoria

Correspondence to: Mampaka Mojapelo

Email:

mojapml@unisa.ac.za

Postal address:

PO Box 392, University of South Africa 0003 ,

South Africa

Dates:

Received: 30 Nov. 2010

Accepted: 21 Aug. 2012

Published: 05 June 2013

How to cite this article: Mojapelo, M.L., 2013, 'Reexamining the relationship between the subject agreement morpheme and (in)definiteness in Northern Sotho', Literator 34(1), Art. \#377, 8 pages. http://dx.doi. org/10.4102/lit.v34i1.377

Note:

This article is partly based on the author's doctoral dissertation, with revision in terms of the arguments. The dissertation was submitted in fulfilment of the degree DLit at the University of Stellenbosch in 2007.

\section{Copyright:}

(C) 2013. The Authors.

Licensee: AOSIS

OpenJournals. This work

is licensed under the

Creative Commons

Attribution License.
The grammatical position of the subject noun phrase in Northern Sotho is to the left of the predicate. The subject agreement morpheme is a compulsory link between the subject noun phrase and the predicate. Scholars have examined the role of this morpheme from various perspectives. It is also extensively documented that the morpheme has dual functions. Its primary function is to mark agreement between the subject and the predicate. Its secondary function is pronominal, whereby it is co-referenced to some antecedent. This article reexamined the primary role of the subject agreement morpheme in Northern Sotho in relation to the interpretation of a subject noun phrase as definite or indefinite. This was accomplished by (1) revisiting existing works that are directly or indirectly linked to (in)definiteness and subject agreement, (2) analysing texts that may facilitate discussion on the issue, and (3) relating the findings from previous works to current analyses. The first hypothesis in this article was that when some class 9 subject noun phrases, denoting persons, agree with the verb stem by a class 1 agreement morpheme, the noun phrases are interpreted as definite. The second hypothesis was that although the subject position is considered predominantly topical and definite it may not categorically exclude indefinite noun phrases. Therefore some indefinite noun phrases may also agree with predicates by means of this morpheme.

Herondersoek van die verwantskap tussen die onderwerpkongruensie-morfeem en (on) bepaaldheid in Noord-Sotho. Die grammatikale posisie van die onderwerpnaamwoordfrase in Noord-Sotho is links van die predikaat. Die onderwerpskongruensie-morfeem is ' $n$ verpligte skakel tussen die onderwerpnaamwoord-frase en die predikaat. Vakkundiges het die rol van hierdie morfeem uit verskillende perspektiewe bestudeer. Dit staan ook vas dat hierdie morfeem ' $n$ tweeledige funksie het. Die funksie is eerstens om die kongruensie tussen die onderwerpnaamwoord en die predikaat te stel, en tweedens om as voornaamwoord na 'n voorafgaande gesprek te verwys. Hierdie artikel ondersoek opnuut die primêre rol van die onderwerpskongruensie-morfeem in Noord-Sotho as ' $n$ funksie van die vertolking van ' $n$ onderwerpnaamwoord as bepaald of onbepaald. Dit word gedoen (1) deur opnuut aandag te gee aan bestaande werke wat regstreeks of onregstreeks met (on)bepaaldheid en/of ' $n$ onderwerpskongruensie-morfeem verbind is; (2) deur enkele tekste te ontleed wat bespreking van die saak kan aanhelp; en (3) deur die bevindinge van vorige werke met die huidige ontleding in verband te bring. Die eerste hipotese in hierdie artikel is dat daar gevalle kan voorkom wanneer naamwoord-frase as bepaald geïnterpreteer kan word as 'n klas 9 naamwoord-frase wat persone denoteer ' $n$ klas 1 onderwerpskongruensie-morfeem oorneem. Die tweede hipotese is dat hoewel die onderwerpsposisie meestal as onderwerp en bepaald beskou word, sluit dit nie onbepaaldenaamwoord-frases uit nie, met die gevolg dat dit kan gebeur dat onbepaaldenaamwoord-frases deur middel van die onderwerpskongruensiemorfeem ook met predikate kan kongrueer.

\section{Introduction}

This article addresses issues that have been studied in various languages prior to this research, including Northern Sotho. The issues relating to definite reference are considered relevant in Northern Sotho because definiteness as a grammatical category is viewed as the grammaticalisation of a semantic and pragmatic category of identifiability, which is available across languages (Lyons 1999). The discussion in this article is based on previous works and opinions and (it is hoped) this will not be the last article on the topic. An account is given of previous views on the role of the subject agreement morpheme or subject marker (SM), also known as the subject concord or subjectival concord (SC), in Northern Sotho sentence structure with regard to the interpretation of the subject noun phrase. The purpose of this article is to review the Northern Sotho situation in light of extant views, of which one is that the noun phrase (NP) in Northern Sotho obscures definiteness 
and that the interpretation is determined from the context (Ziervogel, Lombard \& Mokgokong 1969). Another view is that the subject position is an exclusive definite position (Louwrens 1981). The third view relates to the interpretation of a class 9 subject noun phrase $\left(\mathrm{NP}_{\text {subj }}\right)$ with a class 1 SM (cf. Mokgokong 1975) and its relationship with definiteness. The discussion will begin with a brief background on definiteness in a non-articled language, followed by a discussion of the relationship between definiteness and specificity. Secondly, the grammatical functions of an SM are briefly differentiated in order to isolate the function under discussion. This discussion will cover class 9 personal NPs and the role that a class $1 \mathrm{SM}$ plays in their interpretation and then will consider NPs in general. The discussion will also scrutinise different types of texts.

\section{Defining definiteness}

The phenomenon of definiteness is associated with the presence of definite articles such as the or indefinite articles such as $a$ and $a n$ inEnglish. Lyons (1999) views the grammatical category of definiteness as the grammaticalisation of semantic and pragmatic definiteness, which has to do with whether or not a referent is familiar and therefore uniquely or inclusively identifiable to the addressee. The pragmatic condition of identifiability is widely available across languages (Lyons 1999), including those not grammatically marked for definiteness. Definiteness is linguistically marked in different ways in various languages. Bantu ${ }^{1}$ languages are non-articled. Some of these languages have a nominal preprefix, and others do not. The Nguni languages, such as Zulu and Xhosa, have a nominal pre-prefix, which is used with non-vocatives. There seems to be no clear connection between the pre-prefix and (in)definiteness. Taljaard and Bosch (1988) aver that:

the isiZulu noun has no special form to distinguish between the articles "the" and "a". ... Consequently umfana can be "a boy" or "the boy". The English article must be determined from the context. (p. 31)

According to Bokamba (1971) the Dzamba nominal preprefix is associated with definiteness when it is present in the NP and with indefiniteness when it is absent. However, Bokamba maintains that the nominal pre-prefix is not the equivalent of a definite article. Northern Sotho (like other Sotho languages) does not have a nominal pre-prefix in its structure. Another Bantu language without a nominal preprefix is Swahili. An opinion expressed by both Ashton and Perrott (in Lyons 1999:87) is that the Swahili verb shows agreement with the subject, definite or indefinite, and with definite direct objects.

Definite reference is viewed as inducing the inherent presupposition that the speaker and the addressee share information pertaining to the familiarity, locatability and unique or inclusive identifiability of the referent of the NP within a particular discourse (Jackendoff 1972; Heim 1982; Givón 1995; Lyons, 1999; Cruse 2000). Because it is

1.The word 'Bantu' is used in this article for linguistic classification purposes. It bears no reference to the South African sociopolitical context. non-articled, Northern Sotho relies on other means for definite reference, such as anaphoric and situational factors. Anaphora concerns linguistic co-reference whilst situational factors are non-linguistic. Definite NPs include proper nouns (Chafe 1976; Lyons 1999) because these refer to uniquely identifiable entities.

Indefinite reference, on the other hand, does not include the addressee's familiarity with the referent of the NP. According to Cruse (2000):

the essence of indefinite reference is that the identity of the referent is not germane to the message: that is, nothing hinges on the individual features of the referent, only the class of features indicated are presented as relevant. (p. 308)

Indefinite reference is typically used to introduce referents that are unfamiliar, unknown or new. A speaker would therefore use an indefinite expression if he or she does not find the addressee's familiarity with the referent a prerequisite. It is also possible that the speaker may not have any particular referent in mind when uttering an indefinite NP. This brings in the issue of specificity, which is closely intertwined with definiteness.

A distinction is drawn in the literature between specificity and nonspecificity in the realm of indefiniteness (Hawkins 1978; Chesterman 1991; Enç 1991; Diesing 1992; Lyons 1999; Cruse 2000). Specific indefinites consist of NPs whose referents are familiar to the speaker but not necessarily to the addressee. With regard to nonspecific indefinites, the speaker themselves may not have any particular referent in mind at the time of utterance. Consequently, specific NPs may be either definite or indefinite, whilst nonspecifics are indefinite.

\section{Definite and indefinite reference in Northern Sotho}

In this section the expressions of definiteness and indefiniteness, as explained above, in Northern Sotho are illustrated. Anaphoric reference and situational factors have been identified as some of the factors that facilitate definite reference. Anaphora concerns linguistic co-reference, such as the use of full NPs and pronouns, as illustrated in the following example:

Example 1: Go ile go ile mosadi [a] re ge a boa mo a bego a ile, a makala a ekwa monkgo wa nama. [O] be a sa makatšwe ke lefeela ka gore ... [After a while when the woman returned from where she had gone to, she was surprised by the smell of meat. She was justifiably surprised because ...] (Matsepe 1968:63, author's own translation]).

Example (1) is a continuation of a narrative in which 'a woman' was introduced earlier. The first sentence contains a full NP mosadi [woman] and the second sentence an SM -o [she], which functions as a pronoun. Both NPs have definite reference because they are co-referenced to the referent mentioned earlier in the text. An NP that is non-pronominal and does not appear with any modifier, such as mosadi above, usually serves for definite reference in two main instances. 
The first of these is contrastive reference, such as in example (1), where more than one NP that belongs to the same nominal class was mentioned. In such a case a pronominal $\mathrm{SM}$ would be ambiguous. For instance, in example (1) the previously mentioned NPs in this narrative are mosadi, monna [man] and ngwana [child or baby], all of which belong to class 1 and will therefore have the same SM $-a$ [he or she]. Although the predicate excludes the man and the baby in this case, avoiding the pronominal SM makes the text easy to read. In other cases, however, the predicate may not exclude any of the referents, which makes the pronominal SM a bad option. A synonymous full NP may also be used instead of the identical NP. The second instance involves associative anaphora (Lyons 1999), where the NP refers to an entity that has not been mentioned before, but which can be accessed through association with a previously mentioned NP or text. The following example illustrates associative anaphora:

Example 2: Maabane ke ile ka lebanwa ke [theksi], le tšhelete ke se nayo. Ge re le tseleng [mootledi] a mpotša ka setraeke sa baotledi ba dipese. [Yesterday I was faced with boarding a taxi without even having money. While we were on the way the driver informed me about the bus drivers' strike.] (author's own example and translation)

In Example (2), what makes mootledi [driver] definite is a combination of the association with the previously mentioned theksi [taxi] and the common knowledge that taxis have drivers.

Situational factors include that the referent of the NP is accessed from an extralinguistic environment, such as the physical environment and general knowledge. The following examples illustrate the two extralinguistic factors:

Example 3: Nke o hlokomele [ngwana]; o a hlatša. [Please take care of the child; he or she is throwing up.] (author's own example and translation)

Example 4: Le tla botša monna wa terekere a laolle [holong]. [You will tell the tractor man to offload at the hall.] (author's own example and translation)

Example 5: Re tla ya ge [kgwedi] e balama. [We will go with the onset of the new moon.] (author's own example and translation)

Example (3) illustrates familiarity in the immediate physical environment, if the child is known to be in the immediate vicinity. The referent of the NP in example (4) will be accessible from the broader physical environment, for instance if it is known by the discourse participants to be the only one in a particular area or if it is the only relevant one for a particular purpose. Example (5) illustrates familiarity by general knowledge, as a result of the participants' common awareness that their habitat is the same universe or planet. All five of these examples are illustrative of the speaker's reference to a particular referent and their assumption that the addressee is familiar with the referent and is in a position to locate and uniquely identify it. The speaker may also support their intention for the addressee to uniquely identify the target referent, by providing disambiguating word categories such as determiners. For instance, a Northern Sotho NP may appear with a demonstrative or possessive - $a$ with locative gona or $n t s h e$ [there] as the complement, as illustrated in the following examples:
Example 6: Mohlare [wo] o ratwa ke dinose. [This tree is liked by bees.] (author's own example and translation)

Example 7: Mohlare [wa [gona] o ratwa ke dinose. [The tree in question is liked by bees.] (author's own example and translation)

In Example (6) the demonstrative that appears with mohlare [tree] renders mohlare locatable and uniquely identifiable either in the physical environment or from previous discourse. Reference may also be accompanied by gestures if the referent is to be locatable from the non-linguistic context. The possessive construction in example (7) would typically make mohlare accessible from previous discourse. The syntactic interaction of the NP with the word categories above makes it definite.

Indefiniteness excludes presumed familiarity of the addressee with the referent of the NP. The referent of a specific indefinite NP is familiar to the speaker whilst that of a nonspecific indefinite NP is not. Example (8) and example (9) contain typical specific and nonspecific indefinites, respectively:

Example 8: [Lešilotsoko] le ntshwetše ka mare. [Some fool spat on me.] (author's own example and translation)

Example 9: Ge a ka nyala [lešaedi] ?2 [What if he marries an untidy person?] (author's own example and translation)

Example (8) and example (9) are illustrative of referents that may be unfamiliar to the addressee, hence indefinite. The referent of the NP in example (8) may be familiar to the speaker, visually or by association with the spit. At the time of utterance the addressee's familiarity with the referent is neither established nor assumed. The NP represents a typical specific indefinite. The NP lešaedi [untidy person] can be either specific or nonspecific. It would be regarded as specific if the speaker were referring to a specific person as lešaedi. If the speaker has no specific referent in mind and is merely pointing to a possibility of there being such a person, the NP will be regarded as a nonspecific indefinite. In comparing the two sentences it is evident that example (9) does not offer as much linguistic corroboration as example (8) regarding whether or not the referent of the NP is familiar to the speaker. This is an observation borne out by the past-tense marker -etše in example (8) and the potential aspect marker ${ }^{3}$ $k a$ in example (9).

The next section looks into the relationship between the expressions of definiteness, as explained above, and sentence structure

\section{Definiteness and sentence structure}

This section discusses the views regarding the relationship between definiteness and sentence structure. It focuses on two components that are relevant to this article, namely the subject position and the SM. The functions of the SM are

2.The verb stem suggests that the subject is masculine. For this particular verb a feminine subject would be marked by a passive affix.

3.The past tense marker on the verb indicates that the event is past. Together with the semantics of the verb they confirm the existence of the agent. The potential marker, on the other hand, indicates that the action may or may not happen. It also opens up the possibility that such a person may not exist. 
outlined, and the function under discussion in this article is identified.

\section{The subject position and (in)definiteness}

Trithard (1979:24) observes that in subject-prominent languages such as English and Bantu, the topic of a sentence and the grammatical subject tend to coincide'. Other studies on Bantu languages provide evidence that the subject position is topical or definite, anti-focus or does not accommodate indefinites that are restricted to the postverbal position (Louwrens 1981; Louwrens 1991; Bresnan 1994; Zerbian 2006"; Zerbian 2007; Halpert 2008; Zeller 2008). The opinions on the relationship between the subject position and (in)definiteness on the one hand, and related notions, such as the topic or focus split, on the other, range from hardline to flexible on the issues. Zerbian (2006) finds that, in Northern Sotho, whilst the subject position is not F-marked, some NPs in this position may be under wide focus. Givón (1976) observes that in many languages, including Bantu languages, the subject may be either definite or generic, but is never referential-indefinite. As indicated by Louwrens (1981:30) 'generic nouns always present given information' because they have 'a specific genus or species as unique referent'. Generics are therefore expected to be compatible with syntactic positions reserved for definites. However, according to Carstens et al. (2010), in Lubukusu and Kirundi, nonspecific indefinites do appear in the preverbal subject position.

The following sub-section provides a brief account of the functions of the SM.

\section{Grammatical functions of the subject marker}

The grammatical subject in Northern Sotho (as in other Bantu languages) is linked to the verbal stem by means of an SM, which is obligatory (Givón 1976; Louwrens 1991; Mchombo 2004). This morpheme has two functions. Firstly, it is a grammatical agreement marker, bringing about agreement between the $\mathrm{NP}_{\text {subj }}$ and the predicate. Secondly, it functions as a pronominal argument, for anaphoric co-reference (Bresnan \& Mchombo 1987; Louwrens 1991; Poulos \& Louwrens 1994; Mchombo 2004). The two functions are illustrated in Example (1). The first sentence of example (1) contains the SM $-a$ as grammatical agreement whilst in the second sentence the SM $-o$ has a pronominal function. The pronominal function of the $\mathrm{SM}$ is understood to refer to a known referent and, therefore, its interpretation is not being investigated in this article. It follows that the discussion will focus as much as possible on the subject position, the primary function of the SM, and how it influences the interpretation of the $\mathrm{NP}_{\text {subj }}$ as definite or indefinite.

\section{Subject marker and (in)definiteness in Northern Sotho}

Given the variety of assertions in the works cited in the previous paragraphs, it would seem that definite descriptions 4.Zerbian (2006:204-207) distinguishes between a narrow and a wide focus. are realised, encoded or understood differently even across Bantu languages. In the absence of a grammatical marking on the Northern Sotho NP, the point of departure for definite reading will be the notions of 'familiarity', 'known' and 'given' with respect to the referent, which lead to locatability and unique identifiability. Based on these notions the morphosyntactic disposition of the NP will be observed.

Previous Northern Sotho studies on (in)definiteness present two main findings. The first one is that because Northern Sotho is non-articled, 'the English equivalent must be determined from the context' (Ziervogel et al. 1969:28). As a result, a Northern Sotho sentence, Monna o rêka marôtsê ... in English can be rendered by 'the/a man buys pumpkins' or 'the/a man buys the pumpkins' or in the singular 'the/a man buys the/a pumpkin [lerôtsê]'. Ziervogel et al. (1969) do not indicate differentiation between the subject and object positions in this regard. Following the explanation, NPs in both syntactic positions could be interpreted as either definite or indefinite. Translated sentences are selected from Ziervogel et al. for the purpose of illustration (relevant NPs have been bracketed for convenience):

Example 10.1: [Mahloko] a tšofatša [motho]. [Worries cause a person to grow old.] (Ziervogel et al. 1969:23)

Example 10.2: [Leratorato] le thabiša [basadi]. [True love pleases the women.] (Ziervogel et al. 1969:26)

Example 10.3: [Banna] ba dutše. [The men are seated.] (Ziervogel et al. 1969:34)

Example 10.4: [Ngwana] o lonngwe ke [mpša]. [The child has been bitten by a dog.] (Ziervogel et al. 1969:41)

Example 10.5: [Kgomo] e fula [bjang]. [The cow eats grass.] (Ziervogel et al. 1969:41)

These examples are representative of sentences throughout the grammar. The observation is that concrete nouns (both singular and plural) in the subject position are translated into English as definite. With regard to the object position, the translations are variably either definite or indefinite. Abstract nouns generally have no articles.

The second set of findings emanates from Louwrens's (1981) study of the phenomenon, in which he first explains that new information coincides with indefinite reference, and given information with definite reference. Louwrens (1981; 1991) observes that in Northern Sotho the subject position can only be definite, but the object position can be either definite or indefinite.

Although the position adopted by Ziervogel et al. (1969) suggests that any NP in any position may be either definite or indefinite, and that it will be solved by the context, their English translations display a strong bias in favour of Louwrens's (1981) findings. Studies cited in this section impose no restrictions on the postverbal object position; therefore, the position does not attract much interest. There is also no question that the subject position is more often definite than not. The question is: is new information strictly prohibited from the subject position in Northern Sotho? To find out, instances involving an $\mathrm{SM}$ and how the $\mathrm{NP}_{\text {subj }}$ may 
be interpreted will be revisited. The $\mathrm{NP}_{\text {subj }}$ that will be dealt with first is that of class 9. The discussion will focus on NPs denoting persons because they behave differently from the rest of class 9 NPs with regard to the SM. The discussion will then proceed to noun classes in general.

\section{Subject marker and class 9 [+human] noun phrases}

The class prefix of class 9 is a nasal, which is deleted before polysyllabic stems (Lombard 1985). Class 9 contains a variety of semantic classes of nouns, including those denoting persons. Grammatically, the class $9 \mathrm{SM}$ is $-e$. The primary function (Poulos \& Louwrens 1994) of -e is to mark the NP as subject and to bring it into concordial agreement with the verb stem. Some class 9 nouns denoting persons can additionally agree with the verb stem by means of a class $1 \mathrm{SM}$.

Mokgokong's (1975) observation of a class 9 NP and its appearance with different SM morphemes is reflected in the following excerpt:

Example 11: We should, however, begin by drawing attention to the nice distinction in meaning that is brought about by the different subjectival concords in the following sentences:

Kgoši o sepetše.

In the first sentence the relationship between the speaker and the chief is close, because the utterance may be used by the chief's own subject. In the second sentence the relationship is remote, i.e. the utterance may be used by a non-subject of the chief. (p. 81)

The explanation differentiates the uses of a class 1 and a class 9 SM depending, respectively, on the closeness or the remoteness of the relationship concerned. Put differently, if the speaker is a kgoši's subject, one would expect them to know who their kgoši is, and he would normally be their only kgoši. They may also be in a position to uniquely identify a kgoši which is not theirs. However, the speaker's familiarity with a particular kgoši does not necessarily say anything about the addressee's familiarity with the referent. Regarding the issue of definiteness, the speaker's choice of an SM of either class 9 or 1 for this class 9 [+human] NP may be informed by their presupposition about the addressee's familiarity with the referent. The first sentence seems to be the one in which the speaker expects the addressee to be able to retrieve information about the unique identity of the referent, either from previous mention or situationally. The referent of the NP in the second sentence, however, may or may not be uniquely identifiable to both of them. This is a situation that would be solved with disambiguating strategies, such as pragmatics or appearance with other word categories, as illustrated earlier in this article.

The hypothesis that the choice of class 1 agreement morphology is motivated by mutual awareness of the identity of the referent is further illustrated by considering the $\mathrm{NP}_{\text {subj }}-\mathrm{SM}$ relationship in the following excerpt:

5. Kgoši is a royal leader, by birth - a king or 'chief'.
Example: 12: Leilane o ile go kwa [9-kgoši] 1-a] re badimo ba be le yena, ka pelong a re ba be le yena kgoši ka gore a sa tlile go mo laetša gore magoši ao a mo tšhabago - a tšhaba nong ye e hlobilwego diphego e bilego e ripilwe molomo le dinala. [When Leilane heard the kgoši wishing him godspeed (sarcastically), he returned the benediction because he (Leilane) intended to show him (the kgoši) that kgošis who were afraid of him (the kgoši) were afraid of a vulture whose wings had been clipped, along with the beak and nails.] (Matsepe 1968:26, [author's own translation])

According to the hypothesis put forward in this article, the narrator opted for [9-kgoši] 1-a] re ... and not [9-kgoši] 9-e] re ... because they introduced this particular kgoši to the reader earlier in the text (cf. Matsepe, 1968, p. 1ff). Therefore, the narrator is in no doubt that the reader is familiar with the referent of the NP and can uniquely identify it. This particular choice cannot be attributed to factors such as the animacy hierarchy because not every class 9 [+human] NP has this option regarding a class $1 \mathrm{SM}$. Instead, this 'dual agreement' (own formulation) seems to be available to class 9 [+human] NPs with a limited range of reference, which can also serve as titles and function as if they are proper names. Class 9 [+human] NPs with a less limited range of reference and functions preclude a class $1 \mathrm{SM}$ in its primary function, as shown (by an asterisk) in Table $1^{6}$.

\section{Subject marker and noun classes in general}

A close connection between the primary function of the SM and definiteness has been proven both directly (Louwrens 1981; 1991) and indirectly (Ziervogel et al. 1969) earlier in this article. The finding that the definite NP appears in the subject position and agrees with the verb by the SM has been illustrated in the cited works and is not being questioned. Directly and by implication indefinite NPs are understood to be barred from the subject position. The purpose at issue in this article is to review the situation regarding indefinite NPs and their exclusion from the subject position in Northern Sotho. The two cases that prompted this review were:

Case 1: Sometimes when a simple definite NP is translated from an articled language it acquires a determiner in Northern Sotho, even if it appears in the subject position.

Case 2: Sometimes referents of NPs in the subject position in Northern Sotho are not obviously familiar to the addressee.

Examples relating the above-mentioned cases to the subject(in)definiteness link will be used as diagnostic contexts.

Case (1) is illustrated in the following example, which was extracted from translations of a text by two translators ${ }^{7}$. The example involves the translation of the NP at the beginning of the fourth paragraph of the text. The initial words of the preceding paragraphs of the source text are given here to familiarise the $\mathrm{NP}_{\text {subj }}$ under discussion:

Example 13: Title: Apartheid Museum

[paragraph 1]: The Apartheid Museum is the story of the triumph of the human spirit.

6.For anaphoric reference, any of the class 9 [+human] NPs is compatible with either a class 9 or a class 1 pronominal SM.

7.SA-Venues.com (n.d). Both translators are mother tongue speakers of Northern Sotho. 
TABLE 1: Effect of primary function of SM on class 9 [+human] NPS.

\section{Class 9 [+human] NP}

kgoši 'king or chief'

ngaka 'doctor'

tona 'minister'

tonakgolo 'prime minster'

ntona 'headman'

kgarebe 'maiden'

kgeke 'maiden or girl with loose morals [dialectal difference]'

kgwara 'burdensome person'

presidente 'president'

ambasadara 'ambassador'

ntshesere 'burdensome person'

kgole 'highly pregnant woman'

\section{With class 9 SM -e}

kgoši e ja nama. 'the or a king eats (the) meat'.

ngaka e ja nama

tona e ja nama.

tonakgolo e ja nama.

ntona e ja nama.

kgarebe e ja nama.

kgeke e ja nama.

kgwara e ja nama.

presidente e ja nama.

ambasadara e ja nama.

ntshesere e ja nama.

kgole e janama.
With class 1 SM -o

kgoši o ja nama. 'the king eats (the) meat'.

ngaka o ja nama.

tona o ja nama.

tonakgolo o ja nama.

ntona o ja nama.

*kgarebet o ja nama.

*kgeke o ja nama.

* kgwara o ja nama.

presidente o ja nama.

ambasadara o ja nama

*ntshesere o ja nama

* kgole o ja nama.

$\dagger$, In the case of the descriptive definite NP Maria kgarebe or kgarebe Maria 'The virgin Mary' the two components are never separated.

[paragraph 2]: Beginning in $1948 \ldots$

[paragraph 3]: The Apartheid Museum, the first of its kind, illustrates the rise and fall ...

[paragraph 4]: The museum has been assembled and organised ... Translator 1: [Museamo [wo] o ... [Back translation: This museum is ...]

Translator 2: [Museamo [wa apartheid] o ... [Back translation: museum of apartheid (apartheid museum) is ...]

Translator 1 added a demonstrative $w o$ 'this' and Translator 2 a descriptive possessive modifier ${ }^{8}$ wa apartheid 'of apartheid'. The question is: why do both translators, independent from one another, find it necessary to add words for the NP to refer to the museum which is the topic of the text? Could they be thinking that unless they do so they may not be capturing the essence of what 'the' stands for? Do they simply engage in tautology?

The first example to illustrate case (2) is extracted from the first page of a novel (beginning from the very first word of the text). It is a page that typically introduces the milieu, the characters and their activities.

Example 14: Re llela go phela, re llišwa ke go phela; re llela go phala ba bangwe, re llišwa ke go phalwa ke ba bangwe; re llela tšwelopele, re llišwa ke tšwelopele, ka ge nnete gona bophelo e le peapeano yeo go yona mang le mang a ratago go ba tšhia ya letšatši le lengwe le le lengwe. Re llela go buša, re llišwa ke go bušwa; re llela go huma re llišwa ke bodiidi, gobane nnete gona se sekaone se ka ganwa ke wa mogopolo wa mohuta mang?

[Banna] ba] ohlile maledu kua kgorong, moo megopolo ya bona ešetšego e babaela. Ga se ka phošo ka gore ke matšatši e le leetong le molato woo, ... [We yearn to live, life makes us weep; we yearn to outshine others, we weep when beaten; we yearn for progress, we groan under progress; for life is indeed a contest in which each and everyone wants to be the victor of each and every day. We yearn to rule, we groan when ruled; we yearn to be rich, we groan under poverty, because truly, who in his right mind can refuse the best?

Men are abrasively stroking their beards at the kgoro, where their minds are already limping - [exhausted]. It is understandable because it has been days since they [the minds] have been on a journey with this case ... ${ }^{9}$ ] (Matsepe 1968:1, [author's own translation])

If the referent of NP banna [men] can be accessed directly, or by inference, from the first paragraph, it is familiar to

8.The possessive modifier in general does not disambiguate. It is the complement of $-a$ in this particular descriptive possessive construction that secures unique identifiability.

9.The translation includes adaptations from Serudu (1993:123-124, 165, 182). the reader. In that way, these particular men will have been introduced in the first paragraph so that by the time they are mentioned in the second paragraph the reader knows exactly to which men the narrator is referring. The NP will be regarded as definite. If, on the other hand, the NP's link to the first paragraph cannot be established and there is no other way that the reader could have been familiarised with these men, it is representing new information. If the referent is only being introduced, the NP is regarded as having indefinite reference. What is clear is that the narrator has prior knowledge of the referent's existence, which makes the NP specific. Specifics can be either definite or indefinite.

Another point concerns the predicate and its influence on the interpretation of the NP. For instance, a verb that does not express an isolated event or episode, but rather a regularity, or a constant or characterising feature (Carlson 1977) of the referent of the NP is more likely to render the referent generic than not. In the case of example (14) the verb expresses a particular event at a particular place and, therefore, reference is being made to specific men seated at a particular place. The NP banna in this example is considered incompatible with generic interpretation.

Other examples to illustrate case (2) are extracted from news bulletins. The news bulletin comprises a number of news items that are not necessarily related but must be told in succession. Each item typically introduces a new subject. Some items are familiarised in the headlines and others are not. In the case of television news some items are familiarised by visuals and others are mentioned before the visuals. For a visually impaired listener the visuals are irrelevant. A news bulletin is different from a literary text in that most characters and events in literary texts are linked to previously introduced character(s) or event(s). The following news items from the South African Broadcasting Corporation (SABC), SABC 2 at 20h30, screened on different dates, are used for illustration:

Example 15: Extracts from the news bulletins:

Example 15.1: [Le lengwe [la mafelo a bohwa bja thago] le] ka ba kotsing ya ... ['One of the natural heritage sites may be in danger of ...'] (09 July 2011, [free translation])

Example 15.2: [Dimpša [ť̌e dintši] di] šetše tlalelong marega a ... ['Many dogs are abandoned this winter ...'] (09 July 2011, [free translation]) 
Example 15.3: [Dikaratšhe [tše mmalwa tša go tšhela makhura] di] feletšwe ke makhura ... ['Several filling stations are out of fuel ...'] (12 July 2011, [free translation])

Example 15.4: [Batho [ba go feta masomešupa] ba] hlokofetše ... ['More than seventy people died ...'] [21 December 2011, [free translation])

Example 15.5: [Batho [ba lesome] ba hlokofetše mola ba ba šupago ba gobetše kotsing ... ['Ten people died and seven were injured in an accident ...'] [07 February 2012, free translation]

Example 15.6: [Dikolobe [tša go feta tše sekete] di bolailwe Mpumalanga ... ['More than a thousand pigs have been put down in Mpumalanga ...'] (28 February 2012, [free translation])

The bracketed NPs in these examples seem to meet the criteria for indefiniteness because at the time of utterance only the speaker is familiar with the referent. Chafe (1976:54) explicates that the referent of a definite NP is assumed by the speaker to be 'in the addressee's consciousness' at the time of utterance.

A link between cognition and communication has been attested in various disciplines. On pointing to a strong correlation that exists between a cognitive and a communicative point of departure, Lyons (1977:508) contends that 'it is reasonable to suppose that what the speaker takes as the cognitive point of departure will depend upon its psychological salience for him at the time - upon its being uppermost in his mind'. Hence, the theme or psychological subject would mainly appear in the clause-initial position. According to Chesterman (1991:147) 'the reason definiteness can be inferred from information structure is that there is partial overlap between factors underlying each.' However, Chesterman goes on to indicate that the presence of evidence to the contrary overrules the expected inference from word order to definiteness, for example, in the case of 'all-new clauses where there is no given information to fill the clauseinitial slot' (p. 147).

These views are interpreted as follows: the first one seems to accord better with specificity than with definiteness. Specifics include, but are not limited to, definites. The second one seems to point to a norm, with possible exceptions. Therefore, the views do not seem to indicate conclusively where an indefinite NP may or may not be positioned, in terms of cognition-communication support.

\section{Conclusion}

Noun phrases in the preverbal subject position are understood to be typically generic or definite. However, the decision to place indefinite NPs in that position may not be impossible. Halliday, in Lyons (1977), explains this as follows:

Very often there is nothing that is given, or known, which can serve as communicative point of departure; and, even when there is, the speaker can, if he chooses, decide to make thematic an expression referring to something other than what is given ( $\mathrm{p}$. 508) (cf. also Chesterman 1991:147).

The decision to add determiners to the $\mathrm{NP}_{\text {subj }}$ in the translations in example (13) suggests that the translators are of the opinion that without any determiner, reference may be ambiguous. The fact that the predicate excludes a generic reading which leaves two possibilities, namely definite and indefinite, does not solve the problem. Example (14) and example (15) suggest that the subject position may accommodate NPs representing information other than what is given. In the case of example (14) it may just be the way the narrator prefers to introduce this particular referent and event. The question is: are there grounds for decisions such as those taken in the instances of example (13), example (14) and example (15)?

Firstly, the initial view presented earlier in this article is that in the absence of the article system, the NP in Northern Sotho can be interpreted as definite or indefinite, depending on the context. The second view concludes that the subject position is exclusively definite. However, there are cases where the $\mathrm{NP}_{\text {subj }}$ requires support from other syntactic categories to secure unambiguous reference (cf. example (13)). Secondly, some introductions, announcements and statements, such as example (14) and example (15), may occur without any familiar referent, but may nevertheless contain the clauseinitial $\mathrm{NP}_{\text {subj }}$ It is proposed that these two views should be brought to some sort of reconciliation. This may be accomplished by indicating that whilst the subject position is predominantly generic and definite, accommodation of an indefinite NP, and therefore its appearance with an SM, may not be impossible.

In the matter of class 9 [+human] NPs, the SM -e in its primary function may render a class 9 subject no different from what is summarised in the previous paragraph. However, when a class $1 \mathrm{SM}-0 / a$ is employed in the primary function, it seems to attach familiarity and unique identifiability to the NP.

\section{Acknowledgements Competing interests}

The author declares that she has no financial or personal relationships which may have inappropriately influenced her in writing this article.

\section{References}

Bokamba, G.D., 1971, 'Specificity and definiteness in Dzamba', Studies in African Linguistics, 2(3), 217-238.

Bresnan, J.W., 1994, 'Locative inversion and the architecture of universal grammar', Language 70(1), 72-131. http://dx.doi.org/10.2307/416741

Bresnan, J.W. \& Mchombo, S.A., 1987, 'Topic, pronoun and agreement in Chichewa', Language 63(4), 741-782. http://dx.doi.org/10.2307/415717

Carlson, G., 1977, 'Reference to kinds in English', PhD dissertation, University of Massachusetts, Amherst.

Carstens, V., Diercks, M., Lopez, L., Mletshe, L., Ndayiragije, J. \& Sikuku, J., 2010, 'Properties of subjects in Bantu languages', viewed 08 February 2012, from https://mospace.umsystem.edu/xmlui/handle/10355/10464

Chafe, W.L., 1976, 'Givenness, contrastiveness, definiteness, subjects, topics, and point of view', in C.N. Li, (ed.), Subject and topic, pp. 25-55, Academic Press, New York.

Chesterman, A., 1991, On definiteness: A study with special reference to English and Finnish, Cambridge University Press, Cambridge http://dx.doi.org/10.1017/ CBO9780511519710

Cruse, A.D., 2000, Meaning in language, Oxford University Press, Oxford.

Diesing, M., 1992, Indefinites, MIT Press, Cambridge, Mass.

Enç, M., 1991, 'The semantics of specificity', Linguistic Inquiry 22, 1-25. 
Givón, T., 1976, 'Topic, pronoun and grammatical agreement', in C.N. Li (ed.), Subject and topic, pp. 149-188, Academic Press, New York.

Givón, T., 1995, 'Coherence in text vs. coherence in mind', in M.A. Gernsbacher \& T. Givón (eds.), Coherence in spontaneous text, pp. 59-115, John Benjamins Publishing Company, Amsterdam \& Philadelphia

Halpert, C., 2008, 'Subject position and agreement strategies in Kinande and Zulu', viewed 08 February 2012, from http://web.edu/halpert/www/Site/Papers_files/ linglunch handout13nov.pdf

Hawkins, J.A., 1978, Definiteness and indefiniteness: a study in reference and grammaticality prediction, Croom Helm, London.

Heim, I.R., 1982, The semantics of definite and indefinite noun phrases, University of Massachusetts, Amherst.

Jackendoff, R.S., 1972, Semantic interpretation in generative grammar, MIT Press, Cambridge.

Lombard, D.P., 1985, Introduction to the grammar of Northern Sotho, J.L. van Schaik, Pretoria.

Louwrens, L.J., 1981, 'Relevance of the notions 'given' and 'new' discourse information in the study of North Sotho syntax', South African Journal of African Languages $1(1), 21-49$

Louwrens, L.J., 1991, Aspects of Northern Sotho grammar, Via Afrika, Pretoria.

Lyons, J., 1977, Semantics, vol. 2, Cambridge University Press, Cambridge. http://dx.doi org/10.1017/CBO9780511620614, http://dx.doi.org/10.1017 CBO9781139165693
Lyons, C., 1999, Definiteness, Cambridge University Press, Cambridge. http://dx.doi. org/10.1017/СВ09780511605789

Matsepe, O.K., 1968, Megokgo ya bjoko, Van Schaik, Pretoria.

Mchombo, S., 2004, The syntax of Chichewa, Cambridge University Press, Cambridge. http://dx.doi.org/10.1017/CBO9780511486302

Mokgokong, P.C., 1975, Context as a determinant of meaning with special reference to Northern Sotho, DLit et Phil thesis, University of South Africa, Pretoria.

Poulos, G. \& Louwrens, L.J., 1994, A linguistic analysis of Northern Sotho, Via Afrika, Pretoria.

SA-Venues.com n.d., Gauteng tourist attractions Apartheid Museum, Johannesburg, viewed from http://www.sa-venues.com/attractionsga/apartheid-museum.htm Taljaard, P.C. \& Bosch, S.E., 1988, Handbook of the isizulu, Van Schaik, Pretoria.

Trithard, L., 1979, 'Topicality: An alternative to the relational view of Bantu passive', Studies in African Linguistics 10, 1-30.

Zeller, J., 2008, 'The subject marker in Bantu as an antifocus marker', Stellenbosch Papers in Linguistics 38, 221-254.

Zerbian, S., 2006, 'Expression of information structure in the Bantu language Northern Sotho', PhD thesis, Zentrum fur allgemeine sprachwissenschaft, Berlin.

Zerbian, S., 2007, 'Investigating prosodic focus in Northern Sotho', in E.O. Aboh, K. Hartmann \& M. Zimmerman (eds.), Focus Strategies in African Languages, pp. 55-79, Mouton de Gruyter, Berlin.

Ziervogel, D., Lombard, D.P. \& Mokgokong, P.C., 1969, A Handbook of the Northern Sotho Language, Van Schaik, Pretoria. 